\title{
Effects of estradiol on VEGF and bFGF by Akt in endometrial cancer cells are mediated through the NF- $\kappa B$ pathway
}

\author{
JIEQING ZHANG, HONGLIN SONG, YANQIONG LU, HAIYAN CHEN, SI JIANG and LI LI \\ Department of Gynecologic Oncology, Affiliated Tumor Hospital of Guangxi \\ Medical University, Nanning, Guangxi 530021, P.R. China
}

Received November 7, 2015; Accepted February 2, 2016

DOI: $10.3892 /$ or.2016.4888

\begin{abstract}
Endometrial carcinogenesis may be related to the long-term effects of estradiol with no antagonism. However, how estradiol regulates cell proliferation is unknown. In the present study, through investigating the molecular events involved in estradiol induced angiogenics factors VEGF and bFGF, we found that estradiol induced endometrial cancer cell division, proliferation, migratory and invasive capacity in vitro and upregulated mRNA expression and protein synthesis of VEGF and bFGF. The estradiol-dependent induction of the expression of VEGF and bFGF was blocked by ER inhibitor, AKT inhibitor and $\mathrm{NF}-\kappa \mathrm{B}$ inhibitor (PDTC) in estrogen receptor positive Ishikawa cells and blocked by AKT inhibitor, NF- $\kappa \mathrm{B}$ inhibitor (PDTC) in estrogen receptor negative HEC-1A cells. Moreover, estradiol activation of AKT was also blocked by AKT antagonist. NF- $\kappa$ B activation was restricted by estradiol concentration and time. Estradiol leading to VEGF and bFGF induction was also confirmed by the development of xenograft tumors in vivo. Taken together, our data suggest that estradiol induces the production of angiogenic factors via a mechanism involving AKT-mediated $\mathrm{NF}-\kappa \mathrm{B}$ activation partly in non-genomic manner without the estrogen receptor.
\end{abstract}

\section{Introduction}

Endometrial carcinoma is the third most common gynecological cancer, but its frequency has increased steadily in the last three decades (1). Most women who present with early disease are treated with surgery and/or radiotherapy, giving 5 -year survival rates of $>70 \%$. Approximately one-fourth of those patients go onto develop a recurrence. Although the

Correspondence to: Dr Jieqing Zhang, Department of Gynecologic Oncology, Affiliated Tumor Hospital of Guangxi Medical University, Nanning, Guangxi 530021, P.R. China

E-mail: zjq201008@hotmail.com

Key words: estrogen, endometrial cancer, AKT, NF-кB exact cause of endometrial carcinoma remains unknown, the argument that estradiol somehowis implicated in this carcinoma is becoming increasingly more difficult to refute. On the other hand, the need of molecular-target therapy has increased, especially for recurrent cases. Thus, a better understanding is necessary of the molecular pathways of endometrial carcinogenesis.

Estradiol-induced proliferation for mammary and uterine epithelial cells is primarily mediated by estrogen receptor (ER), which belongs to a steroid receptor superfamily/ thyroid hormone superfamily of transcription factors. This is the classical, or genomic, pathway of the estrogen effect (2). Non-genomic estrogenic effects have been described in a few mammalian tissues and cell lines. For example, Sudhagar et al (3) demonstrated that estradio activated the Akt signaling pathway in a non-genomic manner.

The serine/threonine kinase (Akt), also known as protein kinase $\mathrm{B}(\mathrm{PKB})$, is the cellular homologue of the viral oncogene v-Akt. It functions as a downstream regulator of PI3K signaling, activated by multiple growth factors. It has been demonstrated that a subunit of phosphatidylinositol 3-kinase (PI3-K) including the regulatory and catalytic play a role in $\mathrm{NF}-\kappa \mathrm{B}$ activation by the tyrosine phosphorylation-dependent pathway (4). In addition to its role in inflammation and the suppression of apoptosis, cellular survival, transformation and oncogenesis, the transcription factor $\mathrm{NF}-\kappa \mathrm{B}$ plays an important role in control of the expression of many related genes (5).

Evidence exists suggesting that estrogen-induced angiogenesis appears to occur via induction of various angiogenic factors such as vascular endothelial growth factor (VEGF) and basic fibroblast growth factor (bFGF) $(6,7)$. However, the molecular mechanisms of how estradiol induces the expression of these angiogenic factors are poorly understood. Furthermore, estradiol enhances angiogenesis through a pathway involving platelet-activating factor-mediated $\mathrm{NF}-\kappa \mathrm{B}$ activation. In endometrial cancer cells, regulation of $\mathrm{COX}-2$ protein expression by Akt is mediated through the $\mathrm{NF}-\kappa \mathrm{B} /$ I $\mathrm{B}$ pathway (8). These studies led to the hypothesis that Akt via $\mathrm{NF}-\kappa \mathrm{B}$ plays a role in estradiol-induced angiogenesis. The results from experiments designed to test this hypothesis demonstrated that induction of angiogenesis occurs by increasing the expression of several key angiogenic factors through AKT-dependent NF- $\mathrm{B}$ activation. 


\section{Materials and methods}

Ethics statement. The present study was approved by the Animal Care and Use Committee of Guangxi Medical University. The animal research was carried out with strict adherence to the accepted standards for the Care and Use of Laboratory Animals of China. The protocol was approved by the Committee on the Ethics of Animal Experiments of Affiliated Tumor Hospital of Guangxi Medical University [ethical approval reference: CS2012(28)]. All efforts were made to minimize animal suffering.

Cell culture and reagents. The human endometrial cancer Ishikawa and HEC-1A cell line, positive and negative with estrogen receptor, respectively, were generous gifts from Dr Wei Lihui, Gynecological Oncology Center of Peking University People's Hospital. Cells were maintained at $37^{\circ} \mathrm{C}$ under $5 \% \mathrm{CO}_{2}$ in Dulbecco's modified Eagle's medium (DMEM; HyClone Laboratories, Inc., Logan, UT, USA) supplemented with $10 \%$ fetal bovine serum (FBS; HyClone Laboratories), $100 \mathrm{U} / \mathrm{ml}$ penicillin and $100 \mathrm{mg} / \mathrm{ml}$ streptomycin. The medium was changed every three days.

Proliferation assays. The logarithmic phase cells were digested, centrifuged and labeled with concentration of $5 \mu \mathrm{M}$ CFSE (Molecular Probes, Eugene OR, USA), then 1 $10^{5}$ cells were seeded per well in 6-well plates. When the cells attached, the supernatant was changed with $1 \times 10^{-6} \mathrm{~mol} / \mathrm{l}$ estradiol or vehicle to different 3 -wells, after $30 \mathrm{~min}$, the effect of estradiol or vehicle was terminated through changing the supernatant to DMEM with $10 \%$ FBS, the cells were cultured for 24,48 , 72 and $96 \mathrm{~h}$. Then, flow cytometry (BD FACSCanto ${ }^{\mathrm{TM}}$; BD Biosciences, Piscataway, NJ, USA) was used to detect the proliferation of cells. The results were analyzed by using ModFit LT 3.0 software.

Clone formation assay. Cells were seeded in 6-well plates (500 cells/well), when adhered, they were treated with $1 \times 10^{-6} \mathrm{~mol} / 1$ estradiol, or DMEM as control for $30 \mathrm{~min}$. The medium of 6-wells were all changed to DMEM with 10\% FBS to terminate the effect of estradiol or control. After 7 days, cells were fixed by $95 \%$ methanol for $15 \mathrm{~min}$ and stained with $H \& E$. Clones containing $\geq 50$ cells were counted under the low power microscope $(\mathrm{x} 10)$. The clone formation rate was calculated using the following formula: clone formation rate $(\%)=$ (number of clones/number of seeded cells) x 100\%.

Cell cycle analysis. Ishikawa or HEC-1A $\left(1 \times 10^{6}\right)$ cells were seeded in a 6-well plate respectively, when the cells attached, the supernatant was discarded, and $1.5 \mathrm{ml}$ FBS-free DMEM was added for $24 \mathrm{~h}$ to induce cell cycle in G0 phase. Then, $1.5 \mathrm{ml}$ DMEM was added with $1 \times 10^{-6} \mathrm{~mol} / \mathrm{l} \mathrm{E} 2$ to 3-wells as E2 group, or DMEM only as control. After $30 \mathrm{~min}$, the medium of 6-wells were all changed to DMEM with $10 \%$ FBS to terminate the effect of estradiol or control. The cells were grown continuously at $37^{\circ} \mathrm{C}$ in a humid chamber with $5 \% \mathrm{CO}_{2}$. After $24 \mathrm{~h}$, cells were treated according to the instructions of cycle test plus DNA reagent kit (BD Biosciences) and analyzed by flow cytometry (FCM; BD FACSCanto). The results were analyzed by ModFit LT 3.0 software.
Transwell migration and Matrigel invasion assay. The cell migration/invasion experiment was performed in Transwell mini-chamber (Milipore, Billerica, MA, USA). For Transwell invasion assay, the membrane of the upper chamber was precoated with Matrigel at a 1:3 dilution (BD Biosciences).

After treated with $1 \times 10^{-6} \mathrm{~mol} / 1$ estradiol, or DMEM as control for $30 \mathrm{~min}, 1 \times 10^{5}$ cells were seeded in the upper wells filled with serum-free medium, the lower chambers were filled with complete medium supplemented with $20 \%$ FBS to induce cell migration. After the cells were incubated at $37^{\circ} \mathrm{C}$ for $24 \mathrm{~h}$, the migrated/invasived cells through the membrane to the lower side were fixed, stained with crystal violet and photographed. Five random fields per insert were imaged at x200 magnification. Migrated/invasived cells in the images were counted.

Semi-quantitative RT-PCR and ELISA for VEGF and bFGF expression. After adherence, cells were cultured in DMEM without FBS for $24 \mathrm{~h}$ till $~ 70-80 \%$ confluence. After being pretreated with $25 \times 10^{-6} \mathrm{~mol} / 1$ AKT inhibitor 1L-6-Hydroxymethyl-chiro-inosito12-[(R)-2-0-methyl-3-0octadecylcarbonate] (Alexis Co., Farmers Branch, TX, USA) (AKT inhibitor group, AKTI), or $1 \times 10^{-6} \mathrm{~mol} / \mathrm{l}$ ICI 182,780 (estrogen receptor antagonist; Tocris Bioscience Co., Bristol, UK) (ER inhibitor group, EI), or $100 \mu \mathrm{mol} / 1 \mathrm{NF}-\kappa \mathrm{B}$ inhibitor PDTC; Sigma, St. Louis, MO, USA) (NF-кB inhibitor group, PDTC) for $60 \mathrm{~min}$, cells were stimulated with $1 \times 10^{-6} \mathrm{~mol} / 1$ $\beta$-Estradiol-water soluble (Sigma) (E2 group) for $30 \mathrm{~min}$ while control group was treated with FBS-free DMEM.

Total RNA was extracted from the cells using TRIzol reagent (Fermentas, Burlington, ON, Canada) according to the manufacturer's instructions. The total RNA was reverse transcribed using RevertAid ${ }^{\mathrm{TM}}$ First Strand cDNA Synthesis kit (Fermentas). The sequences for the forward and reverse primers for human VEGF are 5'-GAATCATCACGAAGTGG TGAAGT-3' and 5'-GCACACAGGATGGCTTGAAG-3, respectively. The sequences for the forward and reverse primers for human bFGF are 5'-TATTTCTTTGGCTGCT ACTTG-3' and 5'-TCCAGCATTTCGGTGTTG-3', respectively. The sequences for the forward and reverse primers for human GAPDH are 5'-GAAGGTGAAGGTCGGAGT-3' and 5'-GAAGATGGTGATGGGATTTC-3', respectively. All the sequences were synthesized by Invitrogen (Carlsbad, CA, USA). FastStart Universal SYBR-Green Master (Rox) was from Roche (Indianapolis, IN, USA). The real-time PCR protocol included $94^{\circ} \mathrm{C}$ for $3 \mathrm{~min} ; 40$ cycles of $94^{\circ} \mathrm{C}$ for $30 \mathrm{sec}$, $55^{\circ} \mathrm{C}$ for $30 \mathrm{sec}$ and $72^{\circ} \mathrm{C}$ for $30 \mathrm{sec}$, final extension were $72^{\circ} \mathrm{C}$ for $10 \mathrm{~min}$.

The quantitative determination of VEGF and bFGF in culture supernatant was performed by ELISA kit (Shanghai ExCell Biology, Inc., Shanghai, China) according to the manufacturer's instructions. The absorbance of $450 \mathrm{~nm}$ was measured and the expression of VEGF and bFGF evaluated in the cell culture supernatant.

$N F-\kappa B$ activation. Cells were treated with different concentrations of estradiol $\left(10^{-4}, 10^{-6}, 10^{-8}\right.$ and $\left.10^{-10} \mathrm{~mol} / \mathrm{l}\right)$ for $30 \mathrm{~min}$, or $1 \times 10^{-6} \mathrm{~mol} / \mathrm{l}$ estradiol at different time-points $(15$ and $30 \mathrm{~min}$, 1 and $2 \mathrm{~h}$ ), or $25 \times 10^{-6} \mathrm{~mol} / \mathrm{l} \mathrm{AKT}$ inhibitor for $60 \mathrm{~min}$ following incubation with $1 \times 10^{-6} \mathrm{~mol} / \mathrm{l}$ estradiol for $30 \mathrm{~min}$. Harvested 
cells were washed, centrifuged at $500 \mathrm{rpm}$ for $5 \mathrm{~min}$ and mixed with PBS/phosphatase inhibitor, then nucleoprotein was prepare using nuclear extract kit (Active Motif Co., Carlsbad, CA, USA). Quantitative NF- $\kappa$ B DNA-binding p65 was determined using ELISA-based Trans AM ${ }^{\mathrm{TM}}$ assays (Active Motif) in accordance with the manufacturer's instructions. The kit contain a 96-well plate pre-immobilized oligonucleotide containing the NF- $\kappa \mathrm{B}$ consensus site 5'-GGGACTTTCC-3'. Activated $\mathrm{NF}-\kappa \mathrm{B}$ nuclear extraction is first bound to the attached oligonucleotide. The primary antibody was used to detect an epitope on p65 recognized by NF- $\kappa$ B. An enzyme (HRP)-linked secondary antibody was quantified by spectrophotometry (450 $\mathrm{nm}$ absorbance) to evaluated the $\mathrm{NF}-\kappa \mathrm{B}$ activation.

Western blot analysis. Cells were lysed using lysis buffer with protease inhibitor, after 30-min incubation on ice, centrifuged with 12,000 rpm for $10 \mathrm{~min}$, the supernatant was collected. The protein concentration was determined by BCA (bicinchoninic acid assay; Fermentas). Twenty-five micrograms protein per each lane was separated electrophoretically by $10 \%$ SDS-PAGE gel. The gel was transferred to PVDF membrane, then the membrane was blocked in 5\% non-fat milk in PBS for $2 \mathrm{~h}$ at room temperature followed by washes with $1 \mathrm{X}$ TBST. The membranes were incubated with primary antibodies against phospho-Akt (ser 473), AKT or GAPDH (Santa Cruz Biotechnology, Santa Cruz, CA, USA) overnight at $4^{\circ} \mathrm{C}$. The membrane was washed three times with TBS-T for $20 \mathrm{~min}$ and then incubated for $2 \mathrm{~h}$ with peroxidase-labeled anti-rabbit IgG (KPL, Gaithersburg, MD, USA) at room temperature in 5\% non-fat milk in TBST, subsequently washed with TBST three times for $20 \mathrm{~min}$. The signal was developed by addition of enhanced chemiluminescence solution (Bio-Rad Laboratories, Hercules, CA, USA). The proteins were detected with infrared imaging system. Band intensity was quantified using infrared imaging system. Akt and phospho-Akt (p-Akt) band intensities were normalized to those of GAPDH.

Animal care and experiments. Specific pathogen-free female BALB/C mice were obtained from the Animal Experiment Centre of Guangxi Medical University and maintained in our animal facility. All mice were used at 3-4 weeks of age. Subcutaneous xenograft tumors in BALB/c mice were established by the inoculation of a $0.2 \mathrm{ml}$ cell suspension containing $1 \times 10^{7}$ Ishikawa or HEC-1A cells in each of the 15 mice. When xenograft tumors reached $1 \mathrm{~cm}^{3}$, mice were assigned randomly to one of five treatment regimens once every three days, seven times: i) $25 \mathrm{ml} / \mathrm{kg}$ estradiol (E2); ii) $45 \mathrm{mg} / \mathrm{kg}$ estrogen inhibitor ICI 182,780 (EI); iii) $25 \mathrm{ml} / \mathrm{kg}$ AKT inhibitor (AKTI); iv) $50 \mathrm{mg} / \mathrm{kg} \mathrm{NF}-\kappa \mathrm{B}$ inhibitor PDTC (PDTC); v) vehicle (control) were injected into the abdomen, respectively. Each treatment group consisted of three mice. The day following last inoculation, mice were weighed and sacrificed. Tumor volumes $\left(\mathrm{cm}^{3}\right)$ were calculated by the formula: [(major axis) $\mathrm{x}$ (minor axis $)^{2} / 2$ ]. After the treatment, the tumors were removed and analyzed by immunohistochemistry.

Immunohistochemistry. VEGF, phospho-AKT, AKT and GAPDH antibody (rabbit $\mathrm{IgG}$ ) were purchased from Santa Cruz Biotechnology. bFGF and NF- $\mathrm{BB} / \mathrm{p} 65$ antibody (rabbit
IgG) were from Cell Signaling Technology (Danvers, MA, USA). Normal rabbit IgG as negative control antibody were from Cell Signaling Technology. DyLight 680 goat anti-rabbit $\mathrm{IgG}(\mathrm{H}+\mathrm{L})$ was from KPL.

Tissues were fixed in $10 \%$ formalin buffer, embedded in paraffin, and sectioned at $4 \mu \mathrm{m}$ for consecutive glass slides which were incubated with normal rabbit $\operatorname{IgG}(1: 200$, as negative control), or rabbit polyclonal anti-human VEGF antibody (1:120), or anti-human bFGF antibody (1:120), or p-Akt (Ser473) antibody (1:200), or NF- $\mathrm{B} / \mathrm{p} 65$ antibody (1:200) for $1 \mathrm{~h}$ at room temperature. Slides were rinsed in PBS and incubated with anti-rabbit secondary antibody. The subsequent steps were carried out using the SP (streptavidin-peroxidase) kit (Zymed Laboratories, Inc., South San Francisco, CA, USA) according to the manufacturer's instruction. After DAB solution was applied, slides were counterstained with hematoxylin and then evaluated under a light microscope. Cytoplasmic staining intensity, and the proportion of positive tumor cells were recorded and the staining intensity (0-3) and the area of positive staining $(0$, no staining; $1+,<30 \% ; 2+, 30-60 \% ; 3+$, $>60 \%$ ) were calculated.

Statistical analysis. All statistical analyses were performed with SPSS statistical software (version 19.0). The data are represented as the mean \pm standard deviation (SD). Analysis of variance was used to determine P-value between mean measurements. P-value of $<0.05$ was deemed to be statistically significant. All experiments were conducted in triplicate and repeated two or more times.

\section{Results}

Effect of estradiol on cell biological behavior. To determine the role of estradiol on cell proliferation, Ishikawa and HEC-1A cells were treated with or without $1 \times 10^{-6} \mathrm{~mol} / \mathrm{l}$ estradiol for 24 , 48, 72 and 96 h. Cell proliferation of E2 groups was significantly faster than that in control group in different time-points. The results showed that estradiol can promote Ishikawa and HEC-1A cell division and proliferation (Fig. 1).

To evaluate the impact of estradiol on Ishikawa and HEC-1A cell growth, clone-forming experiment was developed. A total of 500 cells were seeded and treated with $1 \times 10^{-6} \mathrm{~mol} / \mathrm{l}$ estradiol or with DMEM as control for $30 \mathrm{~min}$. After 7 days, the clone formation rate in E2 group was significantly higher than that in control group (Fig. 2C).

The migration experiment was performed to verify the effect on motility of Ishikawa and HEC-1A cells. The cells that managed to traverse the filter to the lower chamber were counted under magnification. The migrating cells in E2 group was significantly increased compared to that in control group (Fig. 2A and D). The invasion capacity of Ishikawa cells was evaluated in Matrigel invasion assays. The number of cells that invaded through the Matrigel and membrane was determined. The invading cells in E2 group was significantly increased compared to the control group (Fig. 2A and D). These results suggest that estradiol may impact tumor metastatic ability in endometrial cancer cells.

To further observe the estradiol function on the cell cycle, $1 \times 10^{6}$ cycle synchronized cells, after serum starvation, were seeded in 6 -well plates and treated with or without $1 \times 10^{-6} \mathrm{~mol} / \mathrm{l}$ 

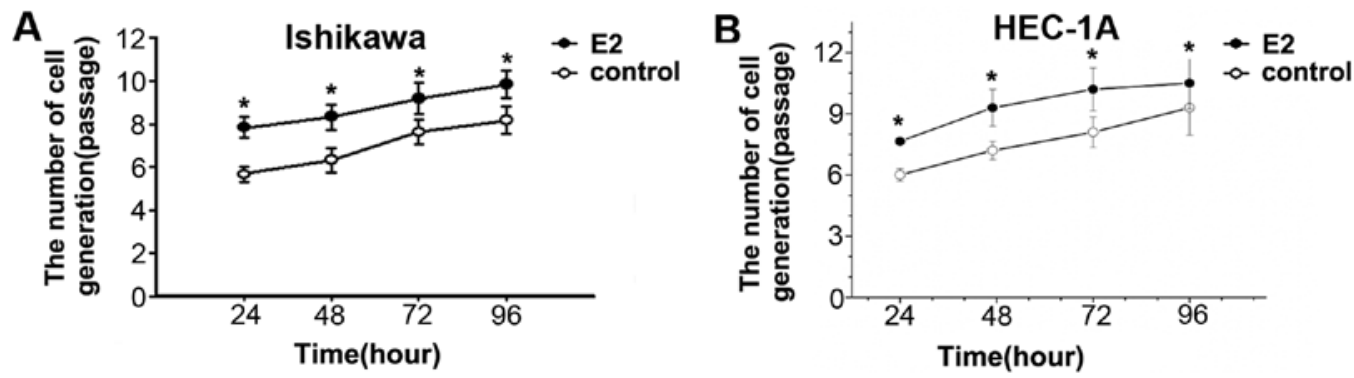

Figure 1. Cell passage detected by CFSE at different times. (A) Ishikawa cell proliferation of E2 and control groups. (B) HEC-1A cell proliferation of E2 and control groups. ${ }^{*} \mathrm{P}<0.05$.

A

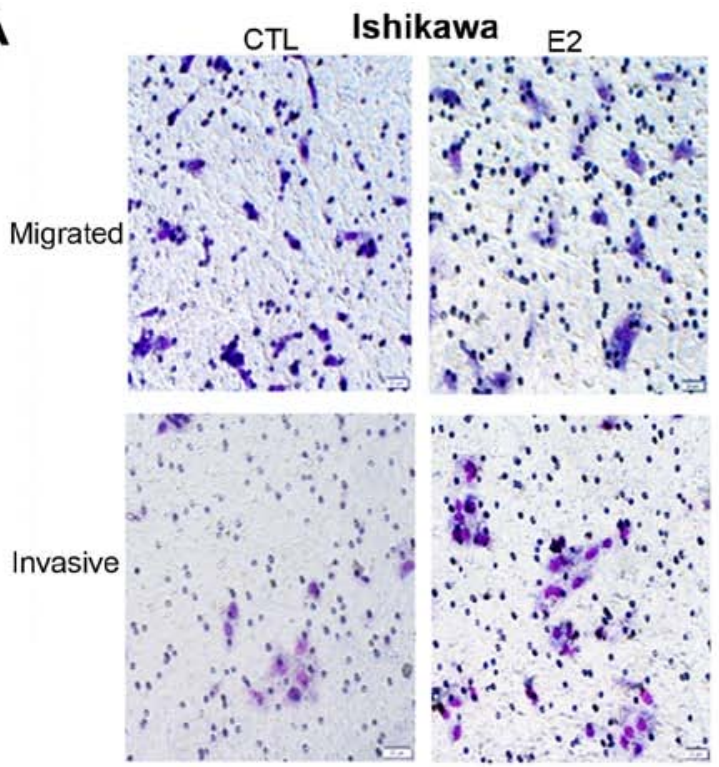

B

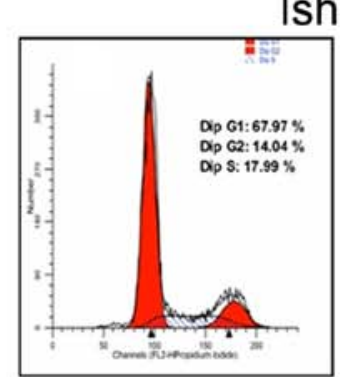

CTL

C

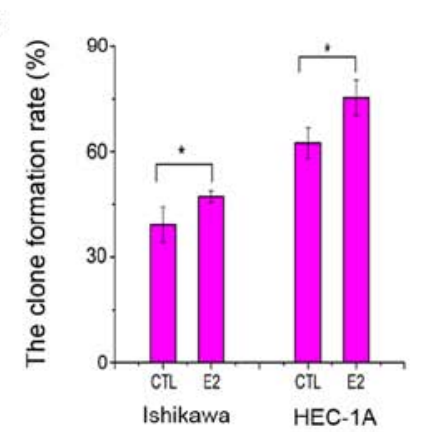

Ishikawa

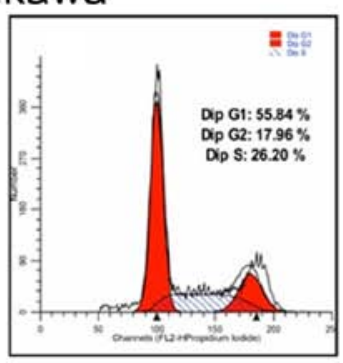

E2
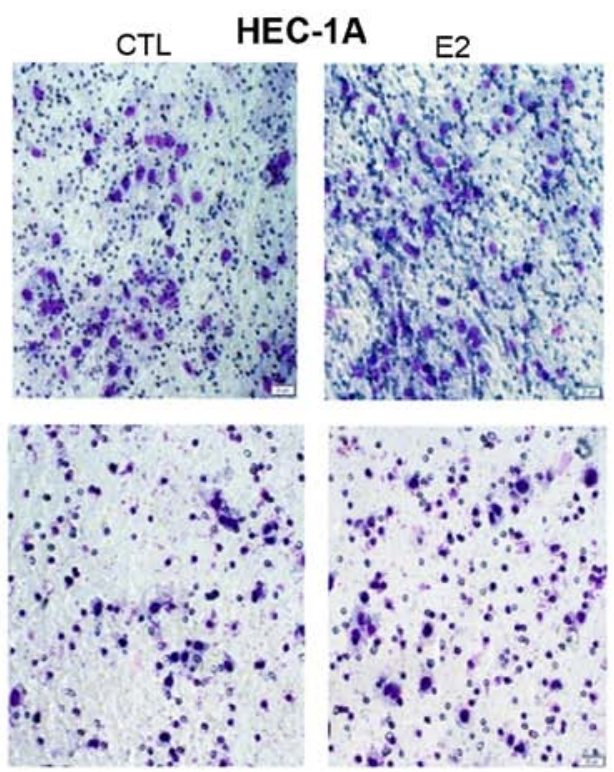

HEC-1A

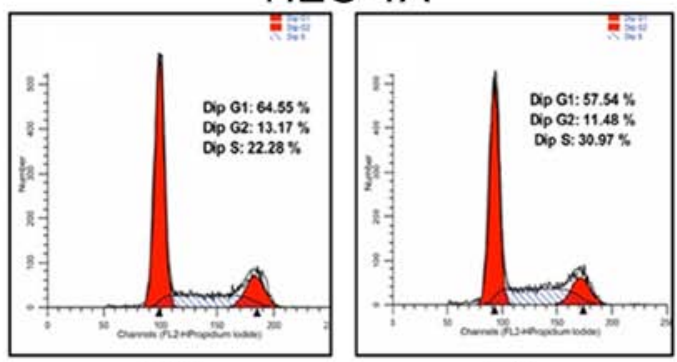

E2
D

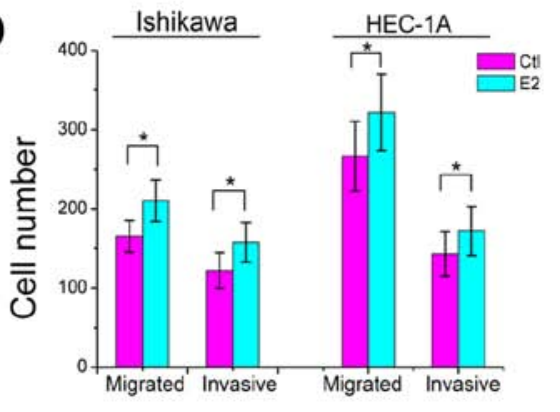

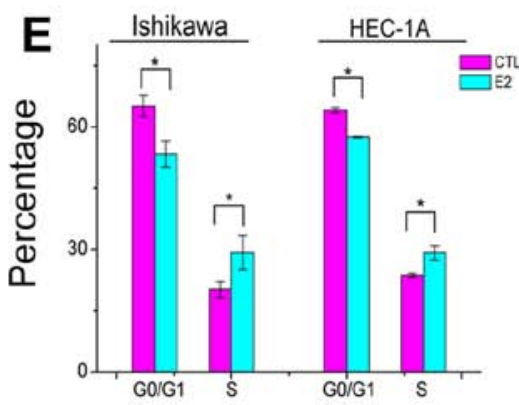

Figure 2. Cells phenotype of Ishikawa and HEC-1A cells. (A) The cell migration and invasion experiment was performed by Transwell mini-chamber. The cells that managed to penetrate the filter to the lower chamber were counted at x20 magnification in 5 different fields per filter. (B) The effect of estradiol on Ishikawa and HEC-1A cell cycles. (C) The clone formation assay. The clone formation rate in E2 group was significantly higher than that in control group either Ishikawa or HEC-1A cell. (D) The migrating and invading cells in E2 group was significantly increased versus control group in either Ishikawa or HEC-1A cells. (E) G0/G1 and S phase percentage of E2 and control groups. For Ishikawa and HEC-1A cell line, G0/G1 cell percentage in E2 group was significantly decreased compared to the control group, $\mathrm{S}$ phase cell percentage in E2 group was significantly increased versus the control group; ${ }^{*} \mathrm{P}<0.05$. 

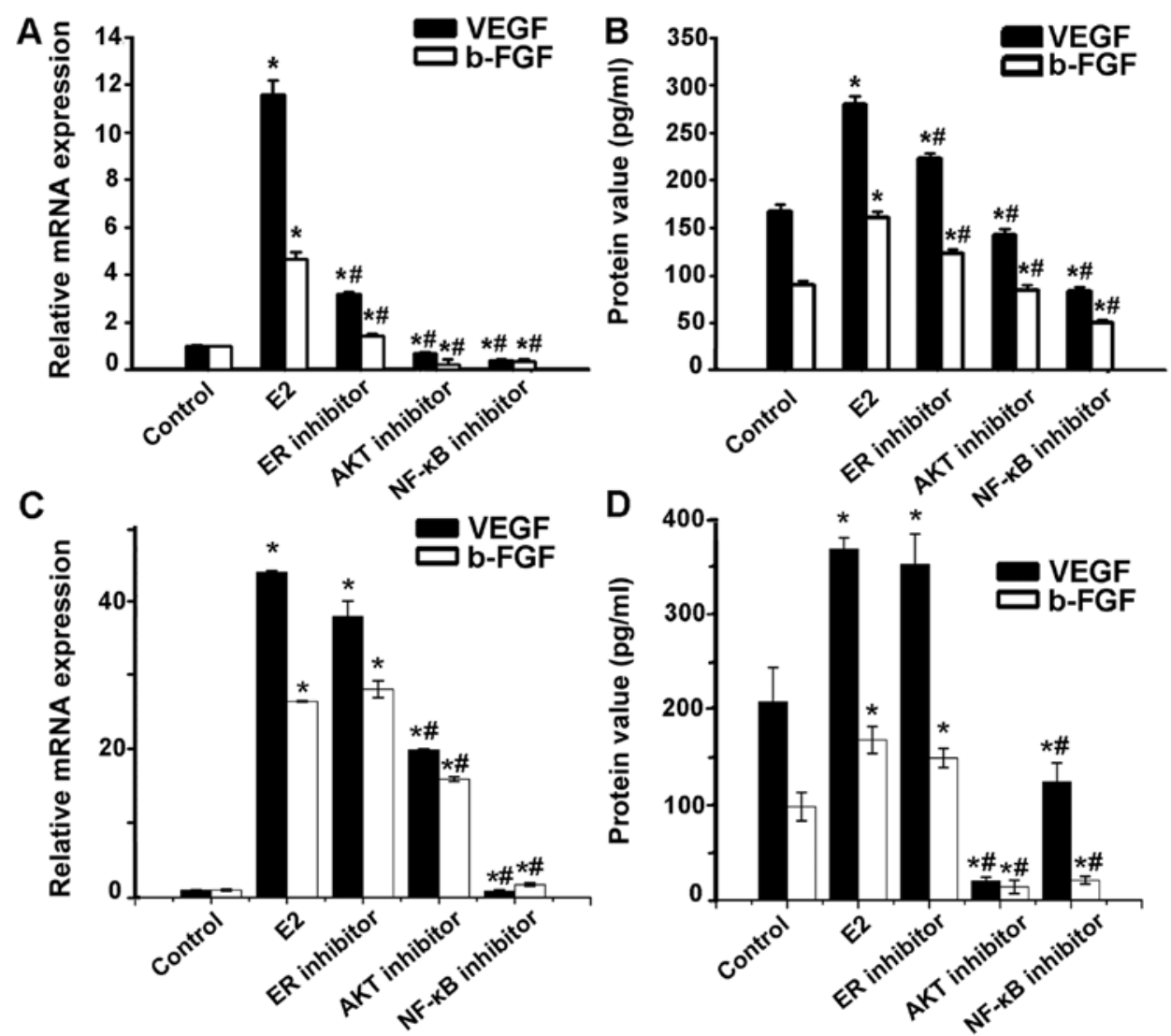

Figure 3. Involvement of AKT via NF- $\kappa$ B in the induction of VEGF and bFGF production by estradiol. (A) VEGF and bFGF mRNA expression in Ishikawa cells pretreated with estradiol receptor inhibitor ICI, AKT inhibitor, NF- $\kappa$ B inhibitor PDTC, respectively, at indicated concentrations before $1 \times 10^{-6}$ mol/1 estrogen treatment was detected through real-time RT PCR. VEGF and bFGF mRNA increase in Ishikawa cells with estradiol treatment could be blocked by estradiol receptor inhibitor ICI, AKT inhibitor, or NF- $\mathrm{BB}$ inhibitor PDTC. (B) VEGF and bFGF protein in the Ishikawa cell culture supernatant was measured by ELISA. VEGF and bFGF protein level tendency was consistent with mRNA expression. (C) VEGF and bFGF mRNA expression in HEC-1A cells pretreated with estradiol receptor inhibitor ICI, AKT inhibitor, NF- $\mathrm{B}$ inhibitor PDTC, respectively, at indicated concentrations before $1 \times 10^{-6}$ mol/1 estrogen treatment was detected through real-time RT PCR. VEGF and bFGF mRNA increased in Ishikawa cells with estradiol treatment could be blocked by AKT inhibitor, or NF- $\mathrm{B}$ inhibitor PDTC, but not by the estradiol receptor inhibitor ICI. (D) VEGF and bFGF protein in the HEC-1A cell culture supernatant was measured by ELISA. VEGF and bFGF protein level tendency was consistent with mRNA expression. Each bar represents the mean \pm SD. ${ }^{*} \mathrm{P}<0.01$, compared with control group; " $\mathrm{P}<0.05$, compared with E2 group.

estradiol for $30 \mathrm{~min}, \mathrm{G} 0 / \mathrm{G} 1$ percentage of E2 groups were significantly lower than that in control groups, percentage of $\mathrm{S}$ phase cells in E2 groups were significantly increased compared to that in control groups (Fig. 2B and E), suggesting that estradiol might stimulate cell proliferation.

Estradiol induced mRNA expression of VEGF and bFGF via Akt induced $N F-\kappa B$ pathway in the endometrial cancer Ishikawa cells. To understand the function of estradiol and angiogenesis in endometrial cancer, we first investigated whether estradiol induced mRNA expression and protein synthesis of the VEGF and bFGF in Ishikawa and HEC-1A cells through real-time semi-quantitative RT-PCR and ELISA for VEGF and bFGF expression. The effect of VEGF and bFGF level increased in Ishikawa cells with estradiol treatment could be blocked by estradiol inhibitor ICI, AKT inhibitor, or NF- $\mathrm{KB}$ inhibitor PDTC. However, the effect of VEGF and bFGF level increased in HEC-1A cells with estradiol treatment could be blocked by AKT inhibitor, NF- $\kappa \mathrm{B}$ inhibitor PDTC, but not by the estradiol inhibitor ICI (Fig. 3), suggesting a role of $\mathrm{Akt}$ and $\mathrm{NF}-\kappa \mathrm{B}$ in estradiol-induced angiogenic factor synthesis.
Effects of estradiol on Akt kinase activity. To determine whether estradiol can also activate the Akt pathway, the ability of estradiol to induce Akt protein expression was determined by western blot analysis. Ishikawa and HEC-1A cells were serum starved for $24 \mathrm{~h}$ and treated with $1 \times 10^{-6} \mathrm{~mol} / 1$ estradiol for $30 \mathrm{~min}$ with or without $25 \times 10^{-6} \mathrm{~mol} / 1$ of Akt inhibitor, or $1 \times 10^{-6} \mathrm{~mol} / \mathrm{l}$ of anti-estradiol ICI 182,780 preincubation for $1 \mathrm{~h}$. We detected total Akt and phosphorylation Akt of Ser473 to evaluate activated serine/threonine kinase function of Akt. The ratio of p-Akt (at Ser473 site)/Akt/GAPDH was used as the level of Akt activation. The results showed that Akt activation was stimulated by estradiol. In contrast, ICI 182,780 and Akt inhibitor inhibited estrogen-induced Akt activation in Ishikawa cells (Fig. 4A and B) while only Akt inhibitor inhibited estrogen-induced Akt activation in HEC-1A (Fig. 4C and D).

$N F-\kappa B$ activation by Akt in endometrial cancer cells. To investigate whether estradiol could regulate NF- $\kappa \mathrm{B}$ activity, we measured its activity in Ishikawa and HEC-1A cells stimulated by varied concentrations of estradiol at $30 \mathrm{~min}$. NF- $\kappa \mathrm{B}$ activity peaked at concentration of $1 \times 10^{-6} \mathrm{~mol} / \mathrm{l}$ estradiol 
A

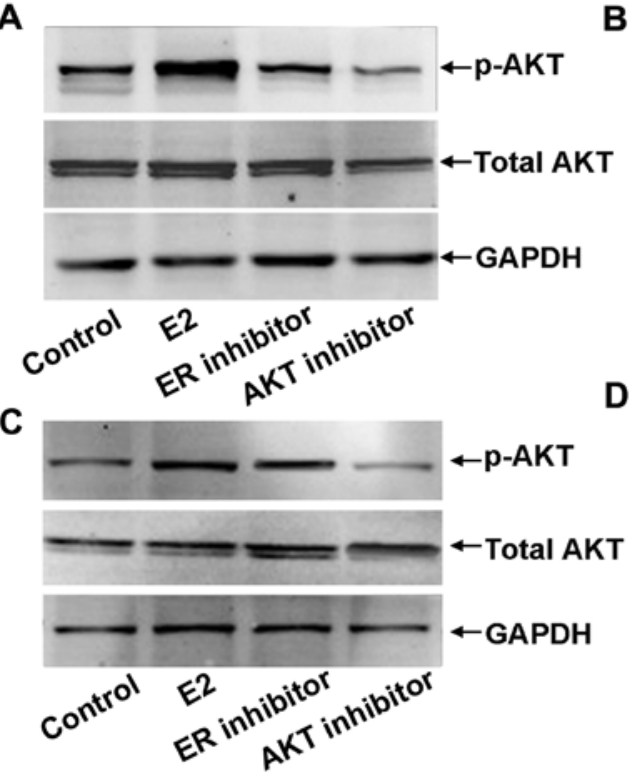

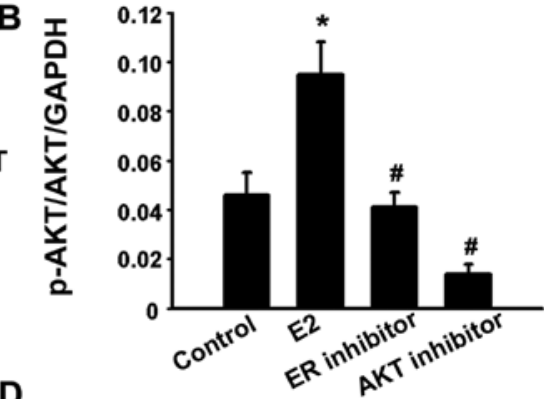

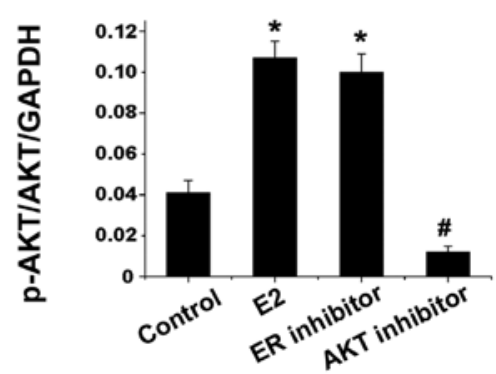

Figure 4. Estradiol induces Akt aictivation in Ishikawa and HEC-1A cells. (A) Expression of activated Akt kinase in Ishikawa cells. (B) Quantitation of the total Akt by western blot analysis normalized by GAPDH levels in Ishikawa cells. Each bar represents the mean \pm standard deviation (SD). "P<0.01, compared with control group; ${ }^{~} \mathrm{P}<0.05$, compared with E2 group. Akt activation was stimulated by estradiol only, ICI 182,780 and Akt inhibitor inhibited estrogeninduced Akt activation. (C) Expression of activated Akt kinase in HEC-1A cells. (D) Quantitation of the total Akt western blot signal normalized by GAPDH levels in HEC-1A cells. Each bar represents the mean \pm standard deviation (SD). "P<0.01, compared with control group; " $\mathrm{P}<0.05$, compared with E2 group. Akt activation was stimulated by estradiol, Akt inhibitor inhibited estrogen-induced Akt activation.

A

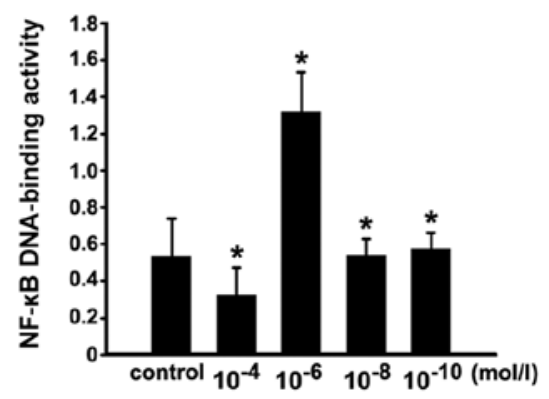

D

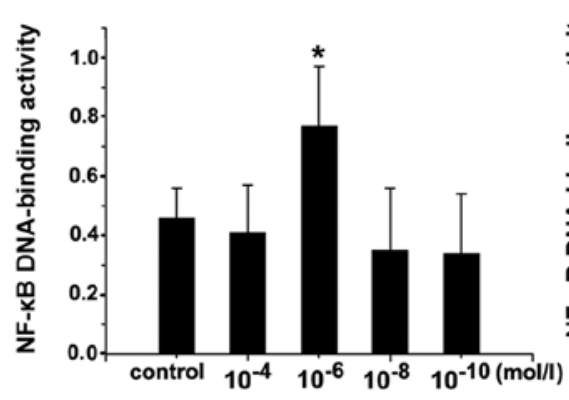

B

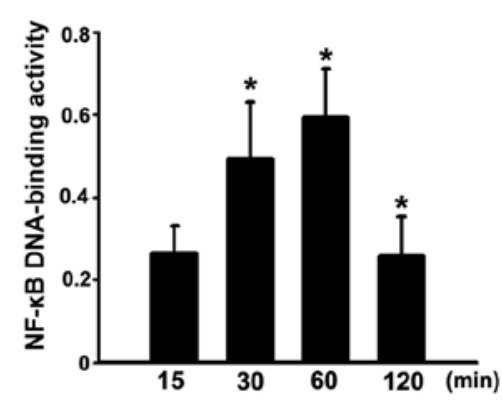

E

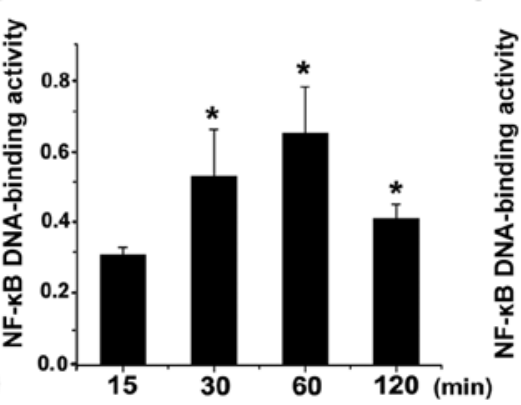

C
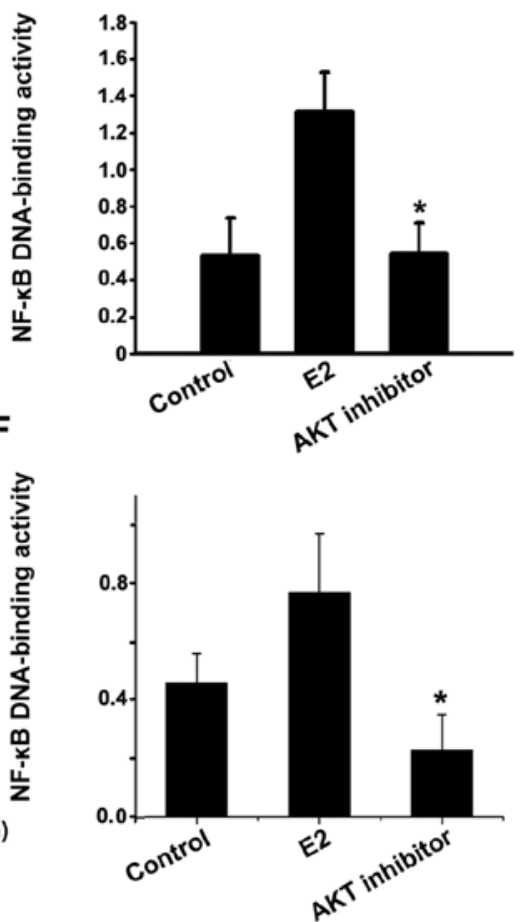

Figure 5. NF- $\kappa$ B activity. (A) The NF- $\kappa$ B activity in Ishikawa cells after stimulated with concentration of $1 \times 10^{-6} \mathrm{~mol} / 1$ estradiol were significantly higher than that in the control group and the other concentration groups $\left(10^{-4}, 10^{-8}\right.$ and $\left.10^{-10} \mathrm{~mol} / \mathrm{l}\right) ;{ }^{*} \mathrm{P}<0.05$. (B) The NF-kB activity in Ishikawa cells after stimulated with $1 \times 10^{-6} \mathrm{~mol} / 1$ estradiol for $30 \mathrm{~min}$ and $1 \mathrm{~h}$ were significantly higher than that in $15 \mathrm{~min}$ and $2 \mathrm{~h} ;{ }^{*} \mathrm{P}<0.05$. (C) Ishikawa cells was incubated with $1 \times 10^{-6}$ mol/1 estradiol for $30 \mathrm{~min}$ (E2 group), or with the AKT inhibitor for $1 \mathrm{~h}$, following incubation with $1 \times 10^{-6} \mathrm{~mol} / \mathrm{l}$ estradiol for $30 \mathrm{~min}$, or vehicle as control. NF- $\mathrm{kB}$ activity in AKT inhibitor group was significantly lower than that in estradiol group. ${ }^{*} \mathrm{P}<0.05$, AKT inhibitor group compared with E2 group. (D) The NF- $\mathrm{kB}$ activity in HEC-1A cells after stimulated with concentration of $1 \times 10^{-6} \mathrm{~mol} / \mathrm{l}$ estradiol were significantly higher than that in the control group and the other concentration groups $\left(10^{-4}, 10^{-8}\right.$ and $\left.10^{-10} \mathrm{~mol} / \mathrm{l}\right) ;{ }^{*} \mathrm{P}<0.05$. (E) The NF- $\mathrm{KB}$ activity in HEC-1A cells after stimulated with $1 \times 10^{-6} \mathrm{~mol} / 1 \mathrm{estradiol}$ for $30 \mathrm{~min}$ and $1 \mathrm{~h}$ were significantly higher than that in $15 \mathrm{~min}$ and $2 \mathrm{~h}$; " $\mathrm{P}<0.05$. (F) HEC-1A cells was incubated with $1 \times 10^{-6} \mathrm{~mol} / 1$ estradiol for $30 \mathrm{~min}$ (E2 group), or with the AKT inhibitor for $1 \mathrm{~h}$, following incubation with $1 \times 10^{-6} \mathrm{~mol} / \mathrm{l}$ estradiol for $30 \mathrm{~min}$, or vehicle as control. NF- $\mathrm{KB}$ activity in AKT inhibitor group was significantly lower than that in estradiol group. ${ }^{*} \mathrm{P}<0.05$, AKT inhibitor group compared with E2 group. Each bar represent the mean $\pm \mathrm{SD}$ of 3 independent experiments. 
A

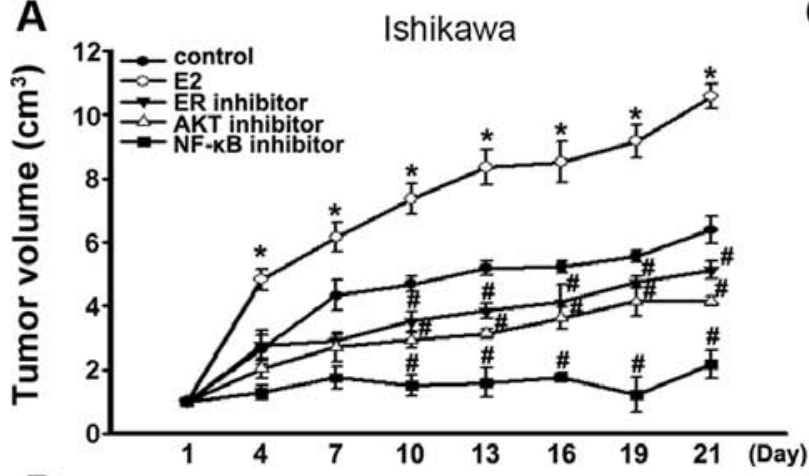

B

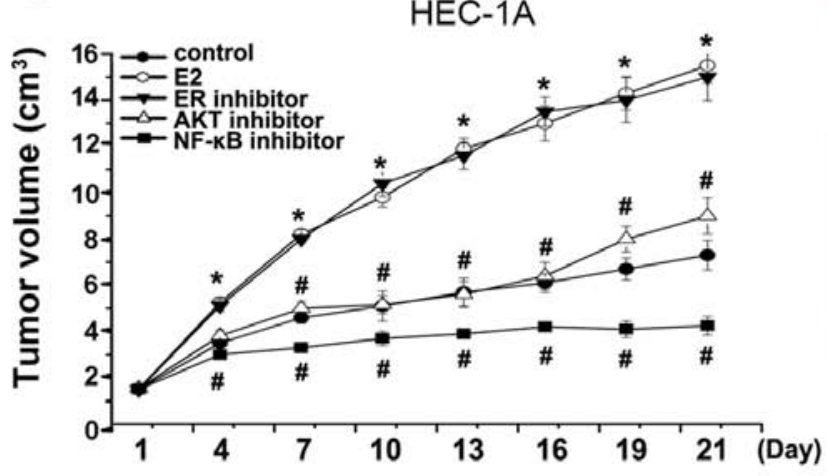

C Ishikawa

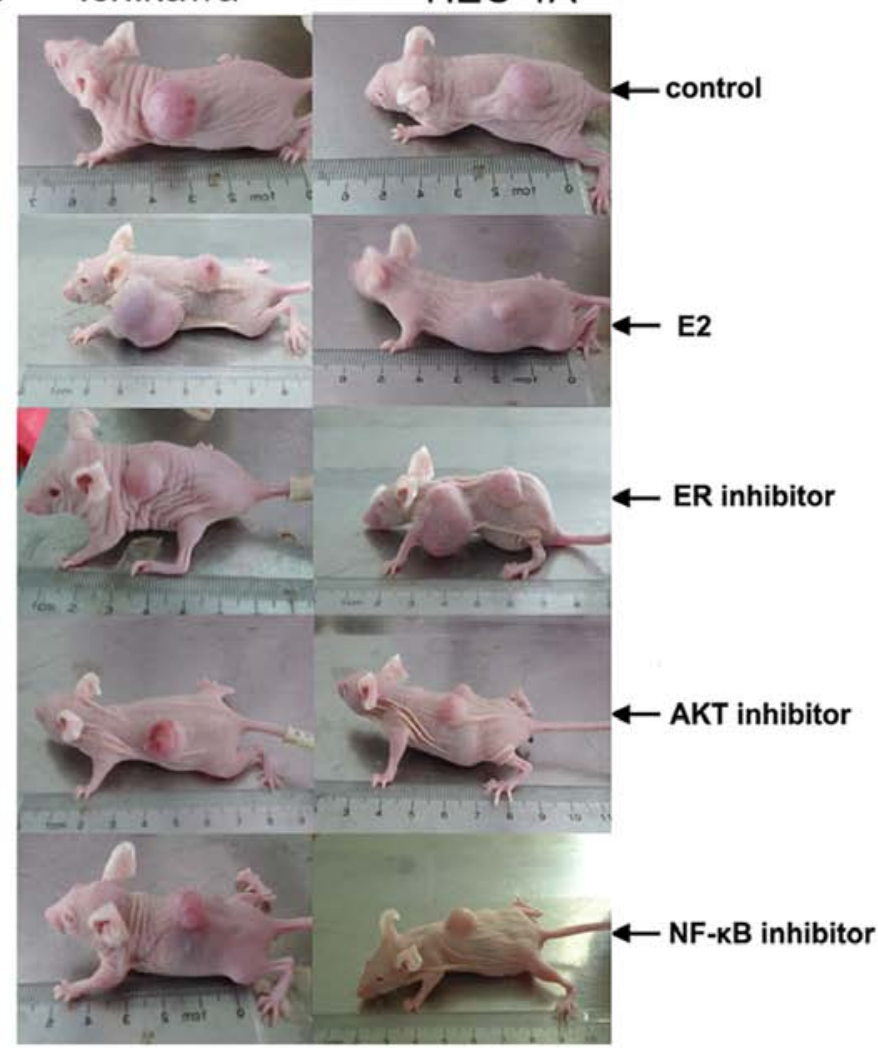

Figure 6. The effect of estradiol and its inhibitor on development of xenograft tumors. Mice were randomly treated with PBS as controls; 25 ml/kg estradiol; $45 \mathrm{mg} / \mathrm{kg}$ estrogen inhibitor ICI 182,780; $25 \mathrm{ml} / \mathrm{kg}$ AKT inhibitor; NF- $\mathrm{B}$ inhibitor PDTC into the abdomen, respectively, once every three days for seven times continuously. The length and width of tumors were measured every two days. (A) Tumor volume of Ishikawa cell model in vivo. (B) Tumor volume of HEC-1A cell model in vivo. (C) The tumor images after the mice were sacrificed at day 21 . "P<0.01, compared with control group; ${ }^{*} \mathrm{P}<0.05$, compared with E2 group.

(Fig. 5A and D). After incubation with $1 \times 10^{-6} \mathrm{~mol} / \mathrm{l}$ estradiol, the level of NF- $\kappa \mathrm{B}$ activity in Ishikawa cells was gradually increased at $30 \mathrm{~min}$ and peaked at $60 \mathrm{~min}$, showing a timedependent manner (Fig. 5B and E). The results indicated that estradiol could induce NF- $\mathrm{BB}$ activation.

To further study the relationship between Akt and NF- $\kappa \mathrm{B}$ activation, Ishikawa and HEC-1A cells were serum starved for $24 \mathrm{~h}$ and then treated with $1 \times 10^{-6} \mathrm{~mol} / \mathrm{l}$ estradiol for $30 \mathrm{~min}$ with or without $25 \times 10^{-6} \mathrm{~mol} / 1$ of Akt inhibitor preincubation. $\mathrm{NF}-\kappa \mathrm{B}$ activity in AKT inhibitor was significantly weaker than that in estradiol stimulation (Fig. $5 \mathrm{C}$ and $\mathrm{F}$ ). Thus, $\mathrm{NF}-\kappa \mathrm{B}$ activity induced by estradiol was blocked by AKT inhibitor pretreatment, confirming that estradiol induced NF- $\kappa \mathrm{B}$ activation by Akt. Taken together, these data demonstrated that estradiol can mediate the expression of VEGF and bFGF through AKT pathway involving NF- $\mathrm{B}$ activation.

Growth of tumors in vivo. To further elucidate the mechanism by which estradiol and Akt-mediated NF- $\mathrm{NB}$ pathway stimulates growth of endometrial cancer cells, we developed Ishikawa and HEC-1A cell-stimulated endometrial cancer model in vivo. In this model, tumors originated from Ishikawa or HEC-1A cells treated with estradiol E2 grew faster than that in control $(\mathrm{P}<0.01)$ (Fig. 6). In Ishikawa cell model in vivo, tumors were smaller in estrogen inhibitor ICI 182,780 alone $(\mathrm{P}<0.01)$, AKT inhibitor alone $(\mathrm{P}<0.01), \mathrm{NF}-\kappa \mathrm{B}$ inhibitor PDTC alone $(\mathrm{P}<0.01)$ compared with that in control. In HEC-1A cell model in vivo, tumors were smaller in AKT inhibitor alone $(\mathrm{P}<0.01)$, $\mathrm{NF}-\kappa \mathrm{B}$ inhibitor PDTC alone $(\mathrm{P}<0.01)$ compared with that in control. Notably, NF- $\mathrm{KB}$ inhibitor PDTC particularly blocked xenograft tumors, compared with estrogen inhibitor or AKT inhibitor. These data showed that tumor continues to grow in response to $\mathrm{E} 2$, but was resistant to its Akt-mediated $\mathrm{NF}-\kappa \mathrm{B}$ pathway inhibitor in the model in vivo of Ishikawa or HEC-1A cells-stimulated endometrial tumors.

We constructed a xenograft model in nude mice by inoculation of Ishikawa or HEC-1A cells. When xenograft tumor was developed to $1 \mathrm{~cm}^{3}$, we investigated the effect after using E2, estrogen inhibitor ICI 182,780, AKT inhibitor, or $\mathrm{NF}-\kappa \mathrm{B}$ inhibitor PDTC through hematoxylin and eosin stain and immunohistochemical methods.

VEGF was detected in the cytoplasm; bFGF, Akt protein and $\mathrm{NF}-\kappa \mathrm{B}$ protein were detected mainly in the endometrial gland epithelium and slightly in cell membrane (Fig. 7A).

The percentage of strong positive expression of VEGF and bFGF in ishikawa cell estradiol group were significant higher than that in control group (both 83.33 vs. 50.0\%). The strong positive expression of VEGF and bFGF using estrogen inhibitor ICI 182,780, or AKT Inhibitor was 0\%, estradiol group was $83.33 \%$, there was a significant difference $(\mathrm{P}<0.05)$. The strong positive expression of VEGF, and bFGF using PDTC were significantly lower than that in E2 group (33.33, 16.67 vs. $83.33 \%),(\mathrm{P}<0.05)$ (Fig. 7B). The strong positive expression rate of Akt protein in ishikawa cell E2 group was much higher 

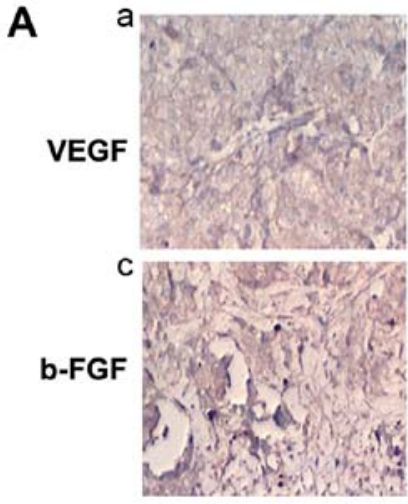

B

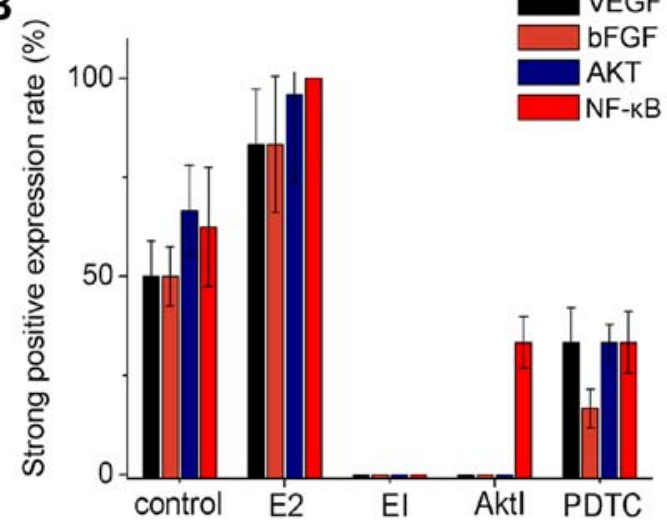

EGF
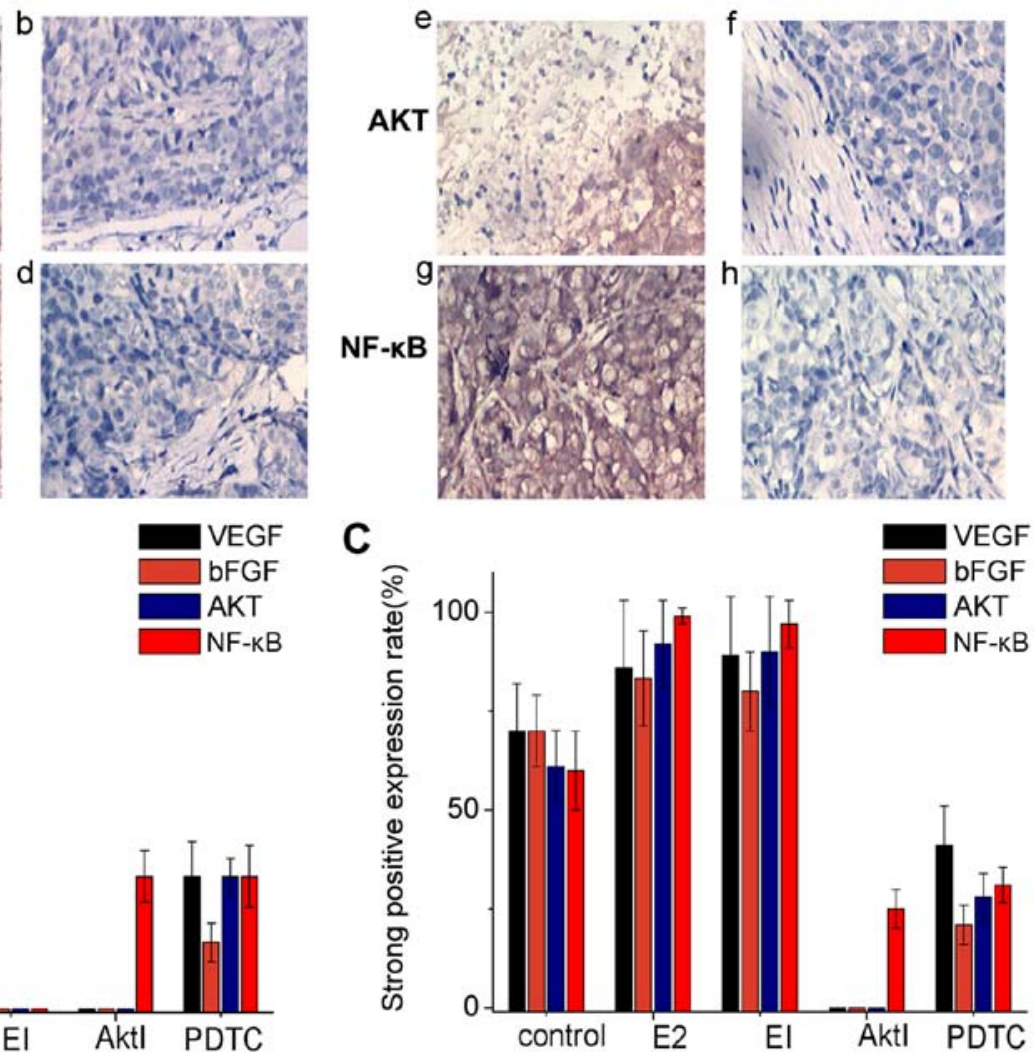

Figure 7. Immunohistochemical experiments in the xenograft model. (A) The a, c, e and g show strong positive immunohistochemical staining of VEGF, bFGF, AKT and NF- $\mathrm{kB}$ images; the $\mathrm{b}, \mathrm{d}$, $\mathrm{f}$ and $\mathrm{h}$ are negative staining images. (B) The histogram of VEGF, bFGF, AKT, NF- $\mathrm{kB}$ strong positive expression in Ishikawa cells. (C) The histogram of VEGF, bFGF, AKT, NF- $\kappa$ B strong positive expression in HEC-1A cells.

than that in control group, EI group, Akt inhibitor group, PDTC group (95.83\% vs. 66.67, 0, 0 and 33.33\%, respectively; $\mathrm{P}<0.05$ all) (Fig. 7B).

The strong positive expression rate of NF- $\mathrm{KB}$ protein in Ishikawa cell E2 group was much higher than that in control group (100 vs. $62.5 \% ; \mathrm{P}<0.05$ ). The strong positive expression rate of NF- $\mathrm{KB}$ protein in EI group, Akt group, or NF- $\mathrm{KB}$ group was significantly lower than that in E2 group $(0 \%, 33.33,33.33$ vs. $100 \%$, respectively; $\mathrm{P}<0.01$ ) (Fig. 7B).

HEC-1A cell line showed almost the same results, except in the group of EI. That is to say, for HEC-1A cell line negative of estrogen receptor, the strong positive expression rate of VEGF, bFGF, AKT and NF- $\kappa$ B protein was not significantly different between the groups E2 and EI.

\section{Discussion}

The actions of estradiol are essential for the growth and survival of tumors that develop from reproductive tissue. Estradiol is thought to exert its biological effects by at least two mechanisms: one termed genomic and the other non-genomic (9). The rapid, non-genomic actions of this sex steroid are attributed to membrane action. However, studies also found that E2 attributed to rapid, non-genomic effects on cell membrane-initiated signaling (10). Many studies show that estradiol can induce Akt activation of PI3K/Akt which is linked to estradiol-induced endometrial epithelial cell proliferation (11). Estradiol can activate Akt rapidly in endometrial cancer while blocked by PI3K inhibitor, 
mediated $\mathrm{NF}-\kappa \mathrm{B}$ pathway. Indeed, our results demonstrated that the NF- $\kappa \mathrm{B}$ activity was induced by different concentrations of estradiol. The estradiol induced NF- $\kappa \mathrm{B}$ activity was blocked by pretreatment with the Akt inhibitor comparing with estradiol treatment, suggesting Akt pathway is essential

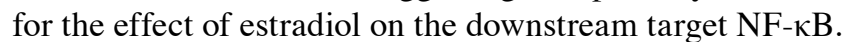

Akt, a major effector protein kinase in the PI3-K signaling, is regulated by steroid hormones (18), growth factors (19) and their receptors (20). ER mediated VEGF and bFGF protein expression were shown to be strictly dependent on Akt pathway which was inhibited by AKT inhibitors in vivo.

High expression of $\mathrm{NF}-\kappa \mathrm{B}$ in breast and endometrial cancer showed a possible important role of $N F-\kappa B$ in promoting proliferation, suppressing apoptosis and promoting cell migration (21-23). The activity of $\mathrm{NF}-\kappa \mathrm{B}$ is tightly controlled by inhibitory $\mathrm{I} \kappa \mathrm{B}$ proteins that bind to $\mathrm{NF}-\kappa \mathrm{B}$ complexes and thus sequester $\mathrm{NF}-\kappa \mathrm{B}$ in the cytoplasm. Upon appropriate stimulation, phosphorylation of I $\kappa \mathrm{B}$ family members by IKB kinase (IKK) complex leading to $\mathrm{NF}-\kappa \mathrm{B}$ nuclear translocation and transcriptional activation. Since Akt phosphorylation has been shown to activate NF- $\mathrm{KB}$ in other systems (24), a similar sequence of events might be involved in phosphor-Akt expressing Ishikawa and HEC-1A cells in the present study.

Regulation of the various key angiogenic factor synthesis such as VEGF and bFGF, are controlled via NF- $\kappa \mathrm{B}$ activity $(8,25)$. $N F-\kappa B$ is an important upstream regulator of VEGF, a major angiogenic factor that induces endothelial cell proliferation (26), promotes tumor-induced angiogenesis. Estradiol-induced angiogenesis appear to be dependent on angiogenic factors such as VEGF and bFGF. In the present study, we demonstrated that estradiol induces Akt production, which subsequently leads to production of angiogenic factors VEGF and bFGF in endometrial cancer cells via the activation of NF- $\kappa \mathrm{B}$, this estrogenic effect was blocked by the estradiol inhibitor ICI, AKT inhibitor, or the NF- $\kappa \mathrm{B}$ inhibitor PDTC in estrogen receptor-positive Ishikawa cell line and blocked by AKT inhibitor, NF-kB inhibitor PDTC in estrogen receptornegative HEC-1A cell line.

To the best of our knowledge, this is the first report demonstrated the critical role of Akt-induced NF- $\kappa \mathrm{B}$ activation in estradiol-mediated angiogenesis which promotes the cell proliferation, clone formation while impacts tumor cell migration and invasion. In the present study, we demonstrate that Akt is involved in estradiol induced angiogenesis because it was observed that the inhibition of Akt or NF- $\mathrm{NB}$ action decreased the effects of estradiol. We have also shown that Akt exerts its biological activity through $\mathrm{NF}-\kappa \mathrm{B}$ activation $(4,17)$. Several investigators have reported a role of $N F-\kappa B$ in angiogenesis $(27,28)$. Because Akt is a critical factor of $N F-\kappa B$ in vivo as well as in vitro (29), any circumstance of release and/or synthesis of Akt abnormally may lead to pathological

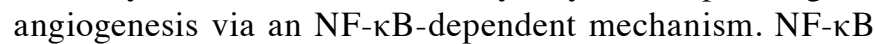
inhibition by parthenolide markedly enhances the sensitivity of resistant breast cancer tumor cells to tamoxifen through suppression of the Akt pathway (30). Thus, in the present study, we have demonstrated that estradiol induces NF- $\kappa \mathrm{B}$ activation through Akt induction in endometrial cells.

Angiogenesis is essential for tumor growth, invasion and metastatic spread. High expression of VEGF and bFGF were significantly associated with histologic grade, vascular invasion and disease progress $(31,32)$. Therefore, VEGF and bFGF are considered as important angiogenic and prognostic factors. In conclusion, our findings demonstrated that estradiol induces the synthesis of key angiogenic factors VEGF and bFGF in endometrial cells through Akt-mediated activation of NF- $\kappa \mathrm{B}$, suggesting the possibility of a potential therapeutic target for human endometrial cancers.

\section{Acknowledgements}

The present study was supported by the National Natural Science Foundation of China (no. 81160318) and the Project of Natural Science Foundation of Guangxi (no. 2013GXNSFAA019219).

\section{References}

1. Siegel RL, Miller KD and Jemal A: Cancer statistics, 2015. CA Cancer J Clin 65: 5-29, 2015.

2. Mangelsdorf DJ, Thummel C, Beato M, Herrlich P, Schütz G, Umesono K, Blumberg B, Kastner P, Mark M, Chambon P, et al: The nuclear receptor superfamily: The second decade. Cell 83: 835-839, 1995

3. Sudhagar S, Sathya S and Lakshmi BS: Rapid non-genomic signalling by $17 \beta$-oestradiol through c-Src involves mTORdependent expression of HIF- $1 \alpha$ in breast cancer cells. Br J Cancer 105: 953-960, 2011.

4. Béraud C, Henzel WJ and Baeuerle PA: Involvement of regulatory and catalytic subunits of phosphoinositide 3-kinase in NF-kappaB activation. Proc Natl Acad Sci USA 96: 429-434, 1999.

5. Wang CY, Mayo MW and Baldwin AS Jr: TNF- and cancer therapy-induced apoptosis: Potentiation by inhibition of NF-kappaB. Science 274: 784-787, 1996.

6. Saarinen NM, Abrahamsson A and Dabrosin C: Estrogeninduced angiogenic factors derived from stromal and cancer cells are differently regulated by enterolactone and genistein in human breast cancer in vivo. Int J Cancer 127: 737-745, 2010.

7. Heaney AP, Fernando M and Melmed S: Functional role of estrogen in pituitary tumor pathogenesis. J Clin Invest 109: 277-283, 2002.

8. St-Germain ME, Gagnon V, Parent S and Asselin E: Regulation of COX-2 protein expression by Akt in endometrial cancer cells is mediated through NF-kappaB/IkappaB pathway. Mol Cancer 3: 7, 2004.

9. Hammes SR and Davis PJ: Overlapping nongenomic and genomic actions of thyroid hormone and steroids. Best Pract Res Clin Endocrinol Metab 29: 581-593, 2015.

10. François CM, Wargnier R, Petit F, Goulvent T, Rimokh R, Treilleux I, Ray-Coquard I, Zazzu V, Cohen-Tannoudji J and Guigon CJ: $17 \beta$-estradiol inhibits spreading of metastatic cells from granulosa cell tumors through a non-genomic mechanism involving GPER1. Carcinogenesis 36: 564-573, 2015.

11. Zhang H, Zhao X, Liu S, Li J, Wen Z and Li M: 17betaE2 promotes cell proliferation in endometriosis by decreasing PTEN via NFkappaB-dependent pathway. Mol Cell Endocrinol 317: 31-43, 2010.

12. Guzeloglu Kayisli O, Kayisli UA, Luleci G and Arici A: In vivo and in vitro regulation of Akt activation in human endometrial cells is estrogen dependent. Biol Reprod 71: 714-721, 2004.

13. Chan TO and Tsichlis PN: PDK2: A complex tail in one Akt. Sci STKE 2001: pe1, 2001.

14. Scheid MP and Woodgett JR: PKB/AKT: Functional insights from genetic models. Nat Rev Mol Cell Biol 2: 760-768, 2001.

15. Madrid LV, Wang CY, Guttridge DC, Schottelius AJ, Baldwin AS Jr and Mayo MW: Akt suppresses apoptosis by stimulating the transactivation potential of the RelA/p65 subunit of NF-kappaB. Mol Cell Biol 20: 1626-1638, 2000.

16. Ozes ON, Mayo LD, Gustin JA, Pfeffer SR, Pfeffer LM and Donner DB: NF-kappaB activation by tumour necrosis factor requires the Akt serine-threonine kinase. Nature 401: 82-85, 1999.

17. Romashkova JA and Makarov SS: NF-kappaB is a target of AKT in anti-apoptotic PDGF signalling. Nature 401: 86-90, 1999. 
18. Bryant DN, Sheldahl LC, Marriott LK, Shapiro RA and Dorsa DM: Multiple pathways transmit neuroprotective effects of gonadal steroids. Endocrine 29: 199-207, 2006.

19. Frago LM, Pañeda C, Argente J and Chowen JA: Growth hormone-releasing peptide- 6 increases insulin-like growth factor-I mRNA levels and activates Akt in RCA-6 cells as a model of neuropeptide Y neurones. J Neuroendocrinol 17: 701-710, 2005

20. Kanda S, Miyata Y and Kanetake H: Fibroblast growth factor2-mediated capillary morphogenesis of endothelial cells requires signals via Flt-1/vascular endothelial growth factor receptor-1: Possible involvement of c-Akt. J Biol Chem 279: 4007-4016, 2004.

21. Biswas DK, Shi Q, Baily S, Strickland I, Ghosh S, Pardee AB and Iglehart JD: NF-kappa B activation in human breast cancer specimens and its role in cell proliferation and apoptosis. Proc Natl Acad Sci USA 101: 10137-10142, 2004.

22. Zhou Y, Eppenberger-Castori S, Marx C, Yau C, Scott GK Eppenberger U and Benz CC: Activation of nuclear factor-kappaB (NFkappaB) identifies a high-risk subset of hormone-dependent breast cancers. Int J Biochem Cell Biol 37: 1130-1144, 2005.

23. Mizumoto Y, Kyo S, Kiyono T, Takakura M, Nakamura M, Maida Y, Mori N, Bono Y, Sakurai H and Inoue M: Activation of NF-kappaB is a novel target of KRAS-induced endometrial carcinogenesis. Clin Cancer Res 17: 1341-1350, 2011.

24. Stice JP, Mbai FN, Chen L and Knowlton AA: Rapid activation of nuclear factor $\kappa \mathrm{B}$ by $17 \beta$-estradiol and selective estrogen receptor modulators: Pathways mediating cellular protection. Shock 38: 128-136, 2012.
25. Abeyama K, Eng W, Jester JV, Vink AA, Edelbaum D, Cockerell CJ, Bergstresser PR and Takashima A: A role for NF-kappaB-dependent gene transactivation in sunburn. J Clin Invest 105: 1751-1759, 2000

26. Shibata A, Nagaya T, Imai T, Funahashi H, Nakao A and Seo H: Inhibition of NF-kappaB activity decreases the VEGF mRNA expression in MDA-MB-231 breast cancer cells. Breast Cancer Res Treat 73: 237-243, 2002.

27. Xiong HQ, Abbruzzese JL, Lin E, Wang L, Zheng L and Xie K: NF-kappaB activity blockade impairs the angiogenic potential of human pancreatic cancer cells. Int J Cancer 108: 181-188, 2004.

28. Stoltz RA, Abraham NG and Laniado-Schwartzman M: The role of NF-kappaB in the angiogenic response of coronary microvessel endothelial cells. Proc Natl Acad Sci USA 93: 2832-2837, 1996.

29. Nakabayashi $\mathrm{H}$ and Shimizu K: Involvement of Akt/NF- $\mathrm{B}$ pathway in antitumor effects of parthenolide on glioblastoma cells in vitro and in vivo. BMC Cancer 12: 453, 2012.

30. deGraffenried LA1, Chandrasekar B, Friedrichs WE, Donzis E, Silva J, Hidalgo M, Freeman JW and Weiss GR: NF-kappa B inhibition markedly enhances sensitivity of resistant breast cancer tumor cells to tamoxifen. Ann Oncol 15: 885-890, 2004.

31. Stefansson IM, Salvesen HB and Akslen LA: Vascular proliferation is important for clinical progress of endometrial cancer. Cancer Res 66: 3303-3309, 2006.

32. Dai H, Zhao S, Xu L, Chen A and Dai S: Expression of Efp, VEGF and bFGF in normal, hyperplastic and malignant endometrial tissue. Oncol Rep 23: 795-799, 2010. 